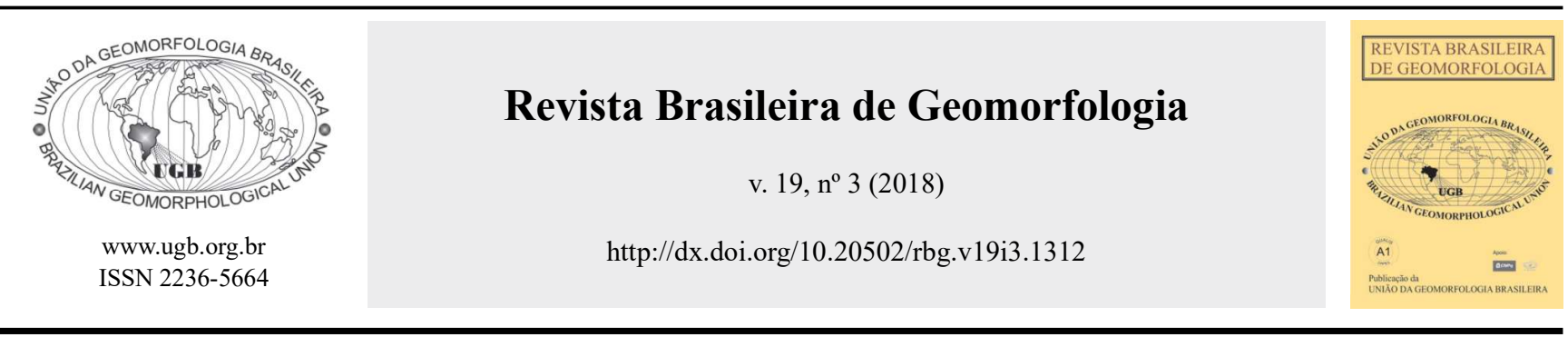

\title{
GEOMORFOLOGIA DOS MACIÇOS COSTEIROS DA REGIÃO METROPOLITANA DE FORTALEZA, CEARÁ
}

\author{
GEOMORPHOLOGY OF THE COASTAL MASSIFS IN THE \\ METROPOLITAN REGION OF FORTALEZA, CEARÁ
}

\author{
Ana Beatriz da Silva Barbosa \\ Departamento de Geografia, Universidade Federal do Ceará \\ Campus do Pici, Bloco 911, Fortaleza, Ceará. CEP: 60455-760. Brasil \\ E-mail: beatrizanna1995@gmail.com
}

Rúbson Pinheiro Maia

Departamento de Geografia, Universidade Federal do Ceará Campus do Pici, Bloco 911, Fortaleza, Ceará. CEP: 60455-760. Brasil

E-mail: rubsonpinheiro@yahoo.com.br

\begin{tabular}{l} 
Informações sobre o Artigo \\
\hline Data de Recebimento: \\
18/09/2017 \\
Data de Aprovação: \\
19/02/2018
\end{tabular}

Palavras-chave:

Geomorfologia; Maciços

Costeiros; Erosão Diferencial;

Lineamentos Estruturais;

Região Metropolitana de

Fortaleza.

\section{Keywords:}

Geomorphology; Coastal Massifs; Differential Erosion; Structural Lineaments.

\section{Resumo:}

Os relevos cristalinos presentes no nordeste setentrional brasileiro correspondem comumente às áreas de expressão plutônica da Província Borborema. Estas morfologias estão associadas às zonas de cisalhamento, que serviram de condutos crustais às intrusões. Dessa forma, os maciços, que constituem o objeto de análise, encontram-se localizados dispostos preferencialmente ao longo de zonas de deformação, onde têm exercido influência nas direções de fraturamento e dissecação. O presente trabalho propôs a análise da evolução geomorfológica dos maciços costeiros localizados na Região Metropolitana de Fortaleza, Ceará, com enfoque nos relevos de Juá/Conceição, Camará, Maranguape e Aratanha, a partir do sensoriamento remoto. O percurso metodológico contemplou a revisão bibliográfica e cartográfica, o processamento digital de imagens e os trabalhos de campo. A análise das variáveis litologia/fraturamento/altitude se deu mediante a extração de lineamentos estruturais obtidos pelos dados SRTM 30m. Nesse cenário, foi realizada a análise do contexto tectônico, estrutural e litológico para a disposição dos maciços, destacando a importância da erosão diferencial. Os resultados apresentaram lineamentos de direções NE-SW, N-S e NW-SE nas unidades litoestratigráficas da Unidade Canindé do Ceará (CC), do Arco Magmático Santa Quitéria (AMSQ) e dos Granitoides Diversos (GD). Os setores fraturados, com maior densidade, estão localizados no embasamento encaixante e acompanham as regiões com falhas e/ou fraturas, delineando as superfícies de erosão. No caso dos granitoides, a baixa densidade de feições lineares, em consonância com sua resistência litológica, responde pelos altos topográficos que estão vinculados às cristas residuais, necks vulcânicos e maciços. 


\begin{abstract}
:
The crystalline reliefs present in the northern Brazilian northeast usually correspond to the plutonic expression areas of the Borborema Province. These morphologies are associated to the shear zones, which served as crustal conduits to the intrusions. Thus, the massifs, which constitute the object of analysis, are located preferably arranged along areas of deformation, where they have exerted influence in the directions of fracturing and dissection. The present work proposes the analysis of the geomorphological evolution of the coastal massifs located in the Metropolitan Region of Fortaleza, Ceará, focusing on the reliefs of Juá / Conceição, Camará, Maranguape and Aratanha, as from data obtained by remote sensing. The methodological course covered bibliographical and cartographic review, digital image processing and field researches. The analysis of the lithology / fracture / altitude variables was obtained through the extraction of structural lineaments ascertained by the SRTM 30m data. In this scenario, the tectonic, structural and lithological context was analyzed for the layout of the massifs, highlighting the importance of differential erosion. The results presented guidelines of NE-SW, N-S and NW-SE directions in the lithostratigraphic units of the Canindé Unit of Ceará (CC), the Santa Quitéria Magmatic Arc (AMSQ) and the Granitoides Diversos (GD). The fractured sectors, with higher density, are located in the surrounding crystalline basement and accompany regions with flaws and/or fractures, delineating the erosion surfaces. In the case of granitoids, the low density of linear features, in consonance with their lithological resistance, is due to the high topographies that are linked to the residual ridges, volcanic necks and massifs.
\end{abstract}

\section{Introdução}

No processo de modelagem do relevo, a configuração litológica heterogênea, em combinação com os sistemas de falhas e fraturas, condiciona os processos erosivos que passam a expressar, no relevo, as direções dos planos de deformação e dos trends estruturais. Seguindo este raciocínio, quatro elementos são fundamentais para a formação dos maciços, bem como de quaisquer unidades morfológicas: estrutura, tectônica, litologia e clima. Dentre as tais, a estrutura é fundamental para subsidiar os processos erosivos, dados pela heterogeneidade presente na litologia (MAIA e BEZERRA, 2014).

O clima constitui uma variável-chave de importante contribuição na evolução das paisagens tropicais, haja vista que, em momentos de calmaria tectônica, a erosão atua de maneira intensa, revelando as estruturas mais profundas do embasamento (MIGON, 2006). As estruturas geológicas podem fornecer controle no modelar do relevo, que podem ser de origem ativa - quando estruturas tectonicamente ativas estão influenciando as morfologias - ou passiva - no caso em que a configuração estrutural pretérita exerce interferência na erosão (BIGARELLA, 2007).

Com frequência, os corpos graníticos situados no nordeste setentrional brasileiro estão associados às principais zonas de cisalhamento brasilianas (NEVES et al., 1995). Na Província Borborema, os sistemas de dobramentos antigos correspondem às áreas mais arrasadas. Por meio da erosão diferencial, cristas residuais, inselbergues e maciços cristalinos destacam as litologias mais resistentes, consoante o trend estrutural dominante (SANTOS e BRITO NEVES, 1984). Enquanto remanescentes de erosão, os maciços se configuram como registros da evolução morfotectônica e morfoclimática, aparecendo na paisagem enquanto cristas alongadas ou sobressaltos topográficos, em virtude de um controle estrutural (MAIA et al., 2016), que confere ao embasamento uma resistência desigual aos processos erosivos.

Os maciços costeiros que constituem o objeto de estudo são representados pelas serras de Maranguape, Aratanha, Juá, Conceição e Camará (Figura 1). Diversas foram as contribuições à geologia e geomorfologia da área de estudo (CLAUDINO SALES, 2016; LIMA, 2014; MAIA e BEZERRA, 2014; BASTOS, 2012; SARAIVA JUNIOR, 2009; CORDEIRO, 2008; VASCONCELOS et al., 2004; CAVALCANTE et al., 2003; CLAUDINO SALES, 2002; BRANDÃO, 1995; SOUZA, 1988; BRASIL, 1981), em projetos de caráter mais abrangente. Todavia, a ausência de trabalhos mais específicos da área, enfatizando a ação estrutural em combinação com a erosão diferencial para a presença das formas, merece ser destacada.

Nessa perspectiva, a contribuição do presente trabalho será a análise da geomorfologia dos maciços costeiros, permeando a gênese e evolução dessas formas, através da interação dos agentes internos (tectônica, litologia e estrutura) e externos (erosão diferencial), 


\section{Geomorfologia dos Maciços Costeiros da Região Metropolitana de Fortaleza, Ceará}

utilizando o processamento de dados geográficos como o principal método. Para tanto, foi estudado o papel do contexto tectônico, estrutural e litológico para a disposição e localização dos maciços, destacando o processo de erosão diferencial na sua posterior individualização. E por fim, apresenta-se uma proposta de evolução da área, considerando a influência dos padrões (direções e densidade) de dissecação exercida sobre a dinâmica geomorfológica da área em questão.

\section{Localização e caracterização da área de estudo}

Os maciços costeiros que constituem a área de análise estão situados na porção norte do estado do Ceará, a nordeste do maciço de Baturité. Os relevos cristalinos de Juá e Conceição estão dispostos numa preferência NNE-SSW; Aratanha e Maranguape em NE-SW; Camará, N-S.

Os maciços possuem altitudes variadas, sendo a mais destacável delas o maciço de Maranguape, com cotas de aproximadamente $920 \mathrm{~m}$, e o maciço de Aratanha, contando com cerca de $750 \mathrm{~m}$. Quanto à Juál Conceição e Camará, estes relevos não ultrapassam os $650 \mathrm{~m}$ de altitude. Estas morfologias representam o ápice do estreitamento das coberturas sedimentares cenozoicas do Ceará, apresentando maciços com altitudes consideráveis distando $4 \mathrm{~km}$ da praia (BRASIL, 1981), como relevos individualizados em meio à depressão sertaneja, aos cones vulcânicos, às planícies fluviais e aos tabuleiros costeiros (Figura 2).
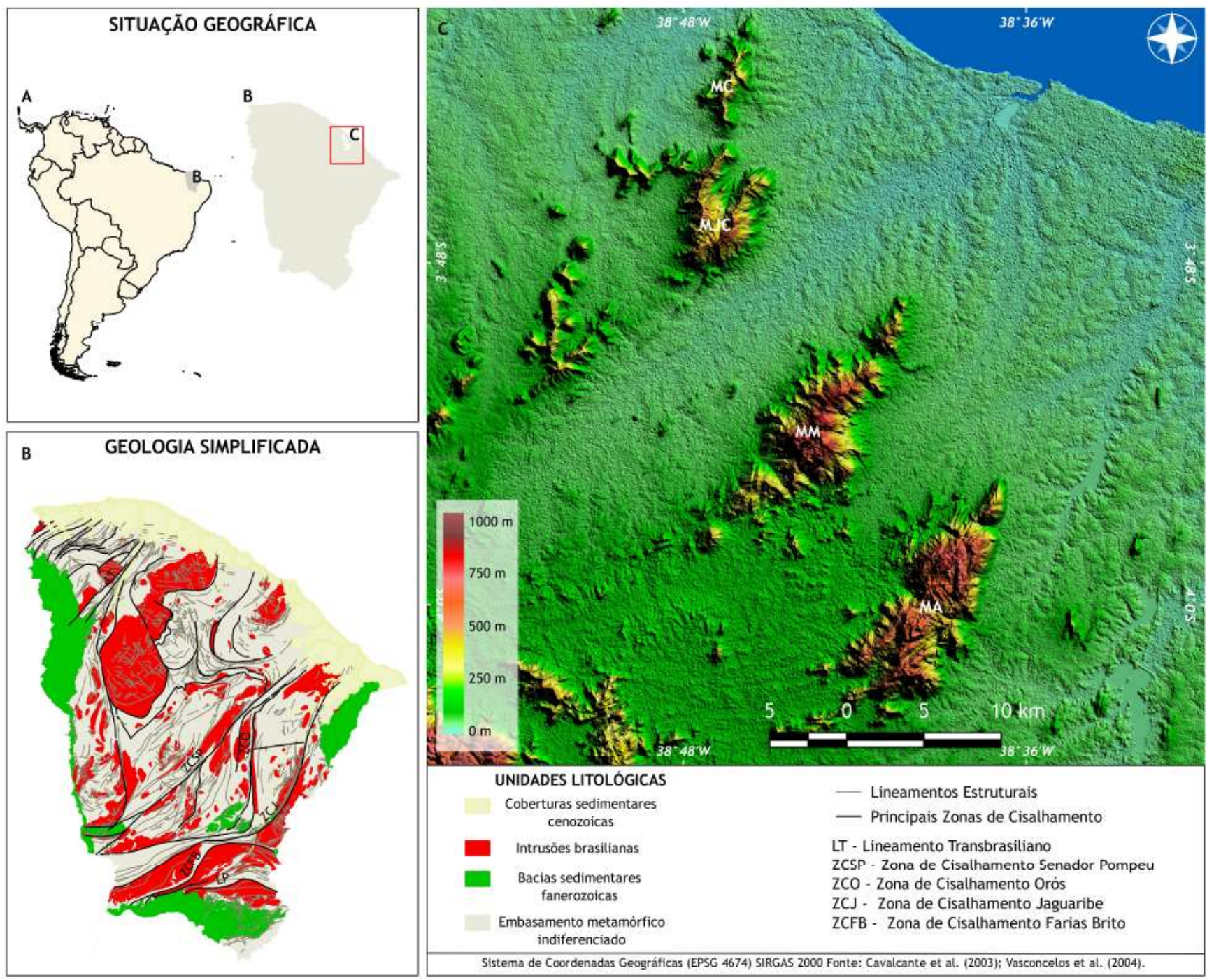

Figura 1 - Localização do setor de pesquisa. A - América do Sul; B-Ceará; C-Área de estudos. MJC-Maciço de Juá/Conceição, MC - Maciço de Camará, MM - Maciço de Maranguape, MA - Maciço de Aratanha. 

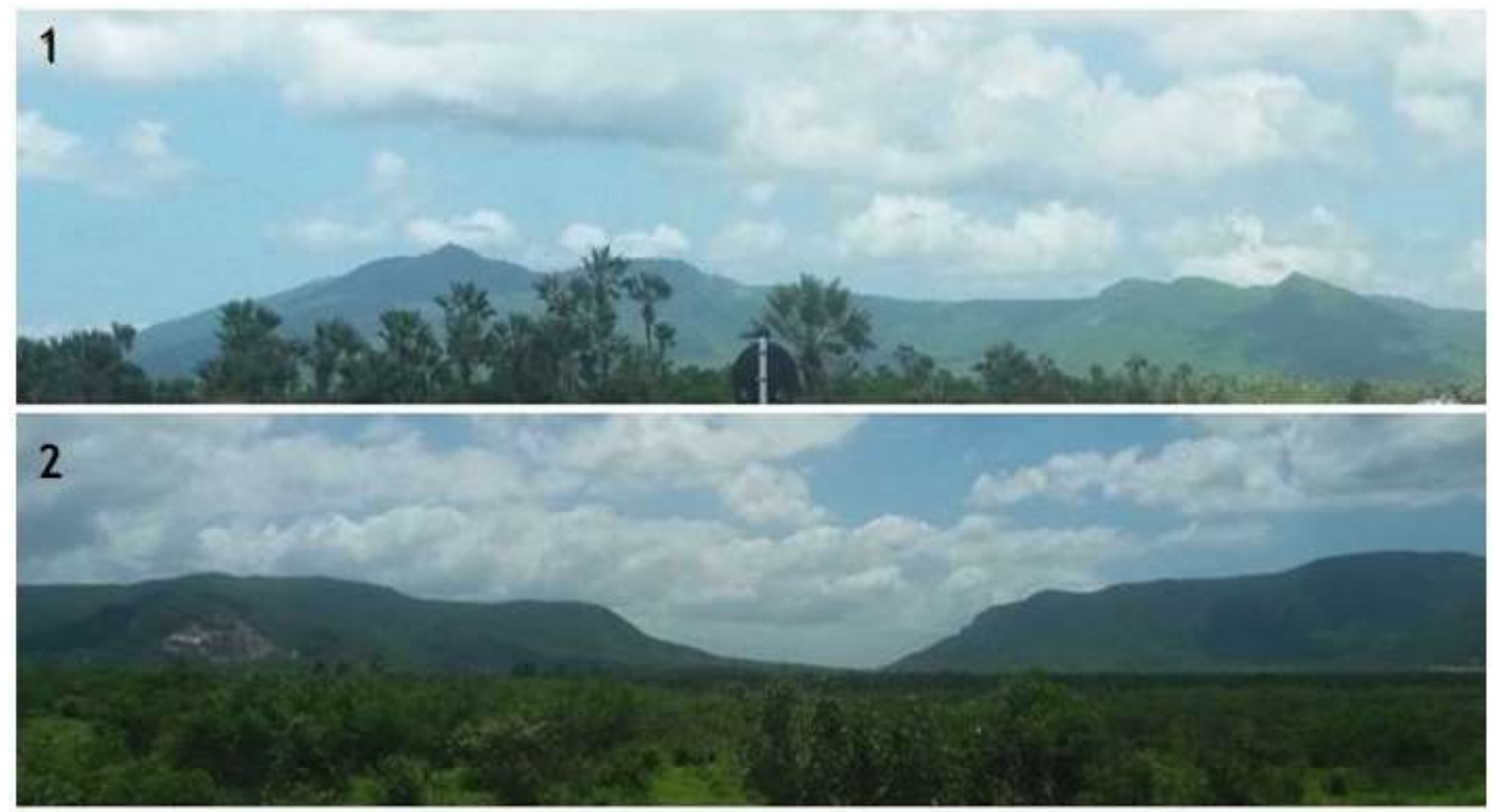

3
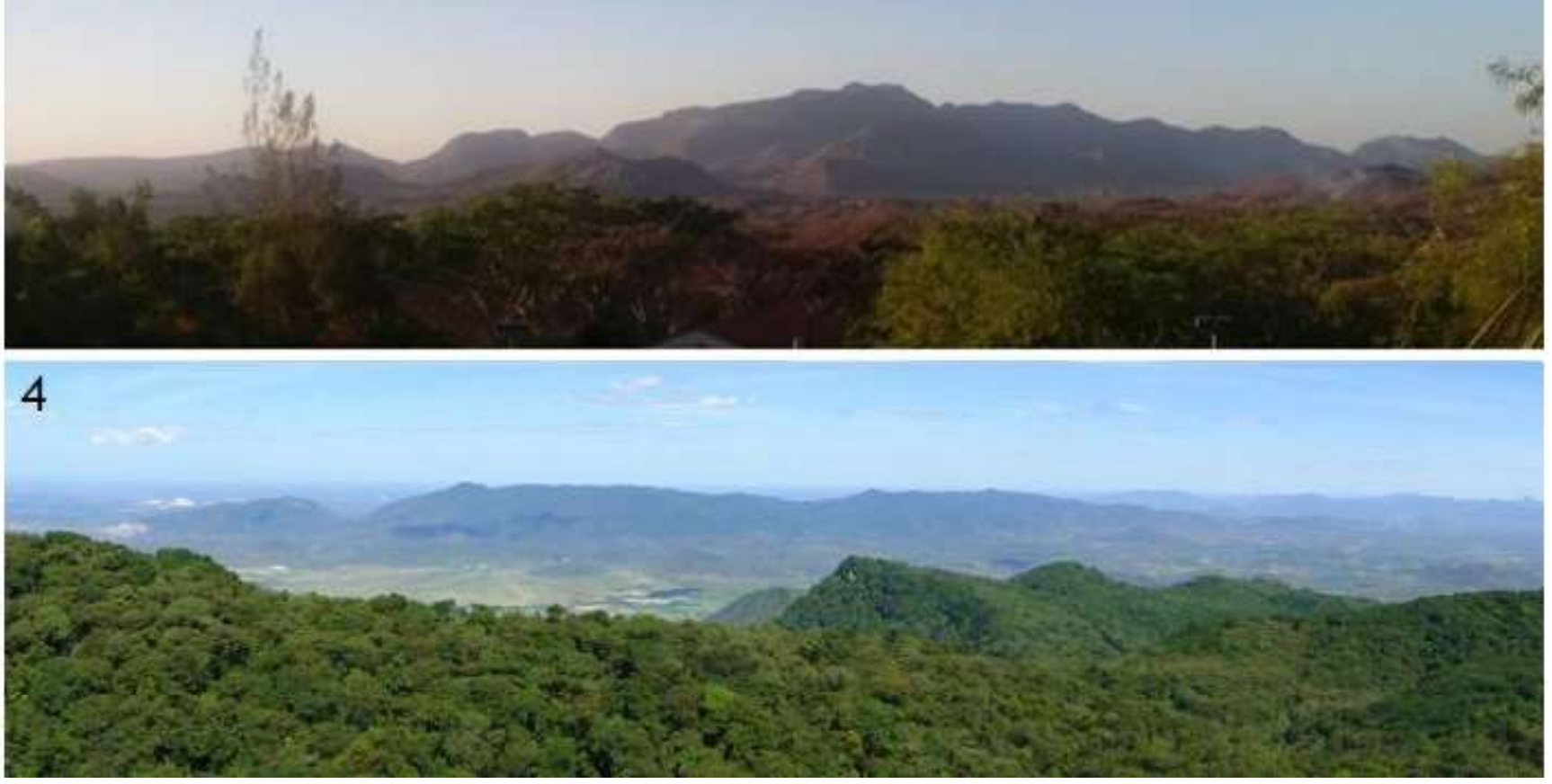

Figura 2 - Fotografias da área de estudos. 1) Maciço de Juá em Caucaia, CE (Fonte: Ana Beatriz Barbosa, 2016); 2) Maciço de Conceição (à direita) e Camará (à esquerda) em Caucaia, CE (Fonte: Ana Beatriz Barbosa, 2016); 3) Maciço de Maranguape no município de Maranguape, CE (Fonte: Ana Beatriz Barbosa, 2016); 4) Maciço de Aratanha, visto do topo do Maciço de Maranguape, município de Maranguape, CE (Fonte: Frederico de Holanda Bastos, 2017).

Os maciços costeiros estão inseridos na Província Estrutural Borborema, que constitui um cinturão orogênico proveniente da convergência dos crátons Amazônico,
São Francisco/Congo e São Luís/Oeste Africano, com terrenos dobrados, deformados e amalgamados no ciclo orogenético neoproterozoico denominado Brasiliano/ 
Panafricano, que formou o supercontinente Gondwana (FETTER et al., 2003; SANTOS e BRITO NEVES, 1984). Essa província encontra-se dividida em domínios demarcados por importantes zonas de cisalhamento e de fraqueza geológica. O objeto de estudo está localizado no Domínio Ceará Central, limitado a oeste pelo Lineamento Transbrasiliano e a leste pela zona de cisalhamento Senador Pompeu (ARTHAUD et al., 2008).

A orogenia brasiliana representa o mais importante dos eventos de acreção continental do Brasil (CLAUDINO-SALES, 2002; 2007), sendo marcada pelas intrusões de inúmeros corpos graníticos à crosta continental (MAIA et al., 2015), bem como na metamorfização de rochas mais antigas e de bacias sedimentares. A colisão provocou, no setor paralelo ao Lineamento Transbrasiliano, uma zona com uma considerável espessura crustal, de direção NE-SW (ARTHAUD, 2007).

Nesse contexto, ocorreu no Domínio Ceará Central uma série de magmatismos, que repercutiram numa sequência de quatro principais atividades, nas seguintes datas: $650-610 \mathrm{Ma} ; 590$ - $560 \mathrm{Ma} ; 540-520 \mathrm{Ma} ; 490$ $460 \mathrm{Ma}$ (COSTA et al., 2013). O Brasiliano ainda pode ser analisado sob dois momentos que são os cavalgamentos das nappes (CABY e ARTHAUD, 1986), num regime compressivo, entre $650-610 \mathrm{Ma}$ e a estruturação de grandes zonas de cisalhamento transcorrentes NNE-SSW entre 590 - $530 \mathrm{Ma}$ (NEVES et al., 1995).

Dentre as litologias que compõem a área de estudo (Figura 3), destacam-se os granitoides, bem como o embasamento adjacente. Os maciços costeiros estão, em sua geologia, ligados à colisão neoproterozoica, constituindo-se basicamente de intrusões graníticas, em momentos sin a pós-colisionais. Os relevos cristalinos do Juá/Conceição e Camará estão situados numa supersuíte intrusiva tardi a pós-orogênica, com granitoides de quimismo indiscriminado, denominados por Cavalcante et al. (2003) como Granitoides Diversos. A litologia de Aratanha e Maranguape pertence à porção granítica do Arco Magmático Tamboril/Santa Quitéria, representando o maior plutonismo sin a pós-tectônico na área de estudo, durante o período Ediacarano (PINÉO e ZWIRTES, 2013; VASCONCELOS et al., 2004).

O Complexo Ceará (CC) constitui um conjunto de bacias que foram metamorfizadas durante a colisão brasiliana, em aproximadamente $630-610$ Ma. A intensidade do metamorfismo dividiu o CC nas unidades Independência e Canindé, sendo que as de grande migmatização foram agrupados no primeiro caso, enquanto que os que exibem condições severas de fusão foram incluídos neste último (ARAÚJO et al., 2012). O CC, em sua consolidação, está associado ao metamorfismo regional ocorrido na orogenia, como também ao cavalgamento das nappes, sendo produto desses, enquanto unidade sedimentar de margem passiva (ARTHAUD et al., 2015; ARTHAUD et al., 2008; CABY e ARTHAUD, 1986). Esta unidade abrange o setor encaixante dos granitoides, compreendendo boa parte da superfície de erosão sertaneja.

O Arco Magmático Santa Quitéria (AMSQ) representa uma das maiores manifestações intrusivas provenientes da Orogenia Brasiliana, no Domínio Ceará Central (FETTER et al., 2003). Consiste em uma associação granítico/migmatítica de rochas plutônicas félsicas de alto potássio, cuja direção preferencial é NESW (ANCELMI et al., 2013). Sua gênese, de cunho sintectônica, é resultante de um metamorfismo de alto grau a ultra-alto grau, desenvolvida entre 650 e $610 \mathrm{Ma}$ (COSTA et al., 2010).

Anteriormente apresentado dentro do denominado Complexo Nordestino (NASCIMENTO et al., 1981), este compartimento geológico compreende setores de migmatitos, metadioritos e de granitoides (PINÉO e ZWIRTES, 2013), com mudanças de fácies, desde gnaisses e gnaisses migmatizados, passando para migmatitos, migmatitos metatexíticos, migmatitos diatexíticos e granitos (BRANDÃO, 1995). Na área de estudo, este vasto compartimento geológico abrange os maciços de Aratanha e Maranguape, com predominância de granitoides, bem como a região mais rebaixada situada entre eles, sob litologia fortemente metamorfizada.

O setor correspondente aos relevos cristalinos de Camará e Juá/Conceição apresenta diversas controvérsias. Os trabalhos executados por Brandão (op. cit.) os inserem no até então chamado Complexo Gnáissico-Migmatítico, com predominância migmatítica, junto ao Serrote do Bico Fino, a sudeste de Juá. A presença de litologia metamórfica foi verificada por Saraiva Junior (2009), sobretudo nas cotas mais elevadas dos maciços. Todavia, sua litologia é inserida na categoria de granitoides brasilianos, através de coletas petrográficas na área, encontrando litotipos graníticos em duas coletas feitas, dentre três no total. Desta forma, convencionou-se enquadrá-los nas delimitações executadas pelo Mapa Geológico do Ceará (CAVALCANTE et al., 2003) e pela carta SA. 24 Fortaleza (VASCONCELOS et al., 2004), que os classificaram como granitoides. 


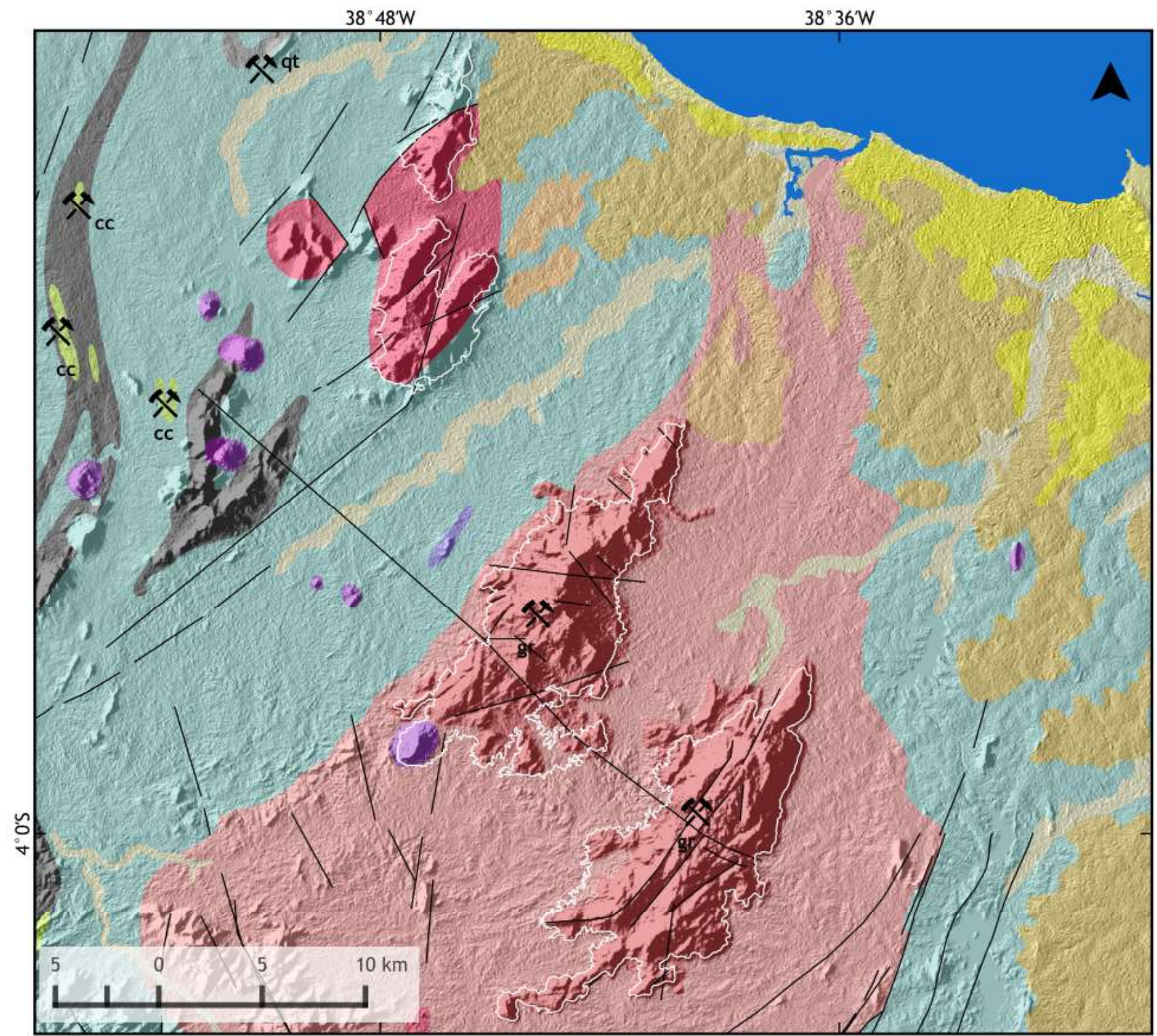

UNIDADES LITOESTRATIGRÁFICAS
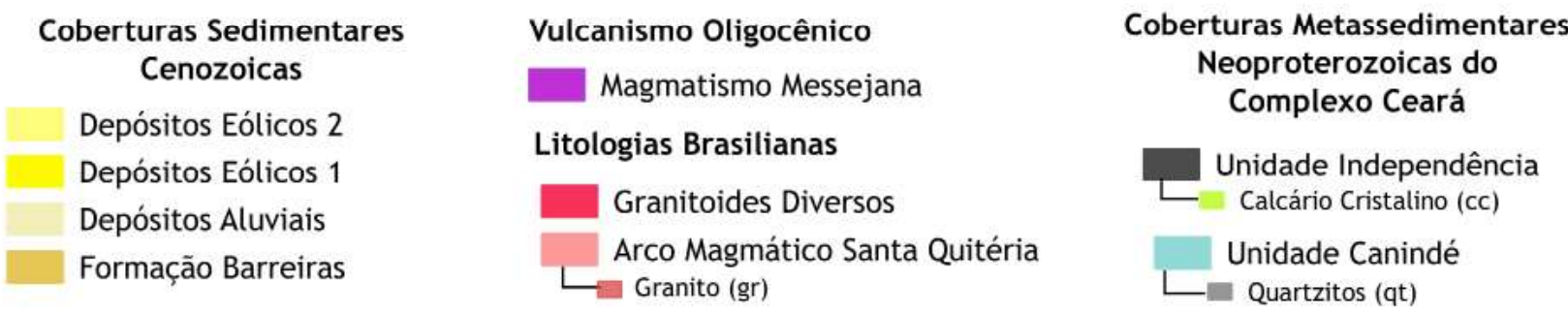

Figura 3-Mapa Geológico. Em linha branca está o contorno dos maciços. E, em linha preta, distribuem-se as falhas geológicas distribuidas mapeadas pelos trabalhos de Brandão (1995), Cavalcante et al. (2003) e Pinéo e Zwirtes (2013).

Os Granitoides Diversos (GD) são produtos dos últimos esforços convergentes brasilianos, com gênese estimada em aproximadamente 560-540 Ma (VASCONCELOS et al., 2004). Os estágios finais da orogenia possivelmente foram responsáveis pelo alívio de pressão que favoreceu a intrusão de corpos graníticos. Estudos elaborados por Cavalcante et al. (2003) apontam uma litologia, de composição granítica dominante, com 


\section{Geomorfologia dos Maciços Costeiros da Região Metropolitana de Fortaleza, Ceará}

fácies porfirítica subordinada, em parte com enclaves dioríticos, que compreende rochas como biotitagranitos, monzogranitos, sienitos, quartzomonzonitos e granitos porfiríticos. A ausência de dados mais detalhados sobre este setor nos leva a presumir que tais intrusões estão inseridas entre o segundo e o terceiro pulso de magmatismo, apresentados anteriormente.

\section{Procedimentos Metodológicos}

O percurso metodológico do presente artigo debruçou-se em quatro principais etapas: 1) $\mathrm{O}$ levantamento bibliográfico, que subsidiou as hipóteses e metodologias da pesquisa; 2) A revisão cartográfica dos dados até então existentes; 3) Utilização do sensoriamento remoto para o processamento de dados geográficos, por meio das imagens SRTM (Shuttle Radar Topography Mission); 4) Os trabalhos de reconhecimento e análises realizadas em campo.

A edição do mapa geológico da área consistiu numa correlação da revisão cartográfica exposta, pois permitiu atualizar os dados, ampliando a análise final. Este procedimento se fez necessário, haja vista a necessidade de maiores detalhes à geologia e estrutura da área. Os arquivos do tipo shape das litologias foram gerados levando em conta os produtos finais de 1995, 2003, 2004 e 2013 dos projetos do Serviço Geológico do Brasil (CPRM).

As informações fornecidas pelas imagens SRTM $30 \mathrm{~m}$ (s04_w39_1arc_v3; s05_w39_1arc_v3) serviram de base para a compartimentação do relevo, bem como para a extração manual dos lineamentos estruturais, resultando na elaboração dos mapas de distribuição e densidade das feições lineares. A fim de alcançar os objetivos propostos fez-se uso dos mapas geológico e geomorfológico, ambos elaborados em ambiente SIG, cujos dados vetoriais foram analisados e editados por meio dos softwares QGIS 2.18.1, Global Mapper 18, SPRING 5.4.3 e ArcGis 10.4.1.

Os dados foram processados, num primeiro momento, a partir da manipulação da imagem SRTM $30 \mathrm{~m}$, responsável por aperfeiçoar a visualização, bem como a posterior análise dos setores com maiores sobressaltos topográficos. Com base no mapa geológico e na extração dos lineamentos estruturais, o procedimento foi possível a partir da correlação entre litologia, estrutura e relevo, utilizando três variáveis: altitude, densidade de lineamentos e geologia. O seu passo a passo envolveu o processamento das imagens SRTM 30 m no software Global Mapper 18, onde foi realizada a extração de curvas de nível e da elaboração de uma palheta de cores no intervalo de $30 \mathrm{~m}$. Esse processo permitiu inferir a declividade e identificar as superfícies de acordo com a dinâmica de erosão e agradação, auxiliando na produção dos mapas de unidades geomorfológicas. A classificação foi baseada nos trabalhos de Maia e Bezerra (2014), Peulvast e Claudino-Sales (2003), Brandão (1995) e Souza (1988).

A escala adotada para a área, numa visão mais abrangente, foi de 1:250.000, sendo setorizada posteriormente para ilustração em 1:130.000, através da disposição em duas porções, a partir da semelhança litológica existente nos maciços: o setor B, representado pelos relevos de Juá/Conceição e Camará e o setor C, ilustrando os maciços de Aratanha e Maranguape. O maior detalhamento da escala serviu para a obtenção de feições lineares.

Os dados matriciais foram tratados em ambiente SIG por meio do Global Mapper 18, onde foi possível realizar o sombreamento das imagens por iluminação horizontal e vertical. A identificação se deu através dos testes azimutais de $0^{\circ}, 45^{\circ}, 90^{\circ}, 270^{\circ}$ e $315^{\circ}$ (Figura 4) com altura 60 , em virtude da melhor visualização e percepção mais real da área.

A extração manual dos lineamentos se deu levando em conta as feições lineares negativas resultantes do sombreamento das imagens SRTM. Como o objetivo da extração foi de entender a influência dos setores de fraqueza na dissecação, para a obtenção dos dados de fraturamento, somente os lineamentos negativos foram considerados.

Com base nos parâmetros de intervalo igual do ArcGis, foi ainda estabelecida a quantidade de cinco classes para categorizar a densidade linear, de acordo com a resposta do software ao cálculo do comprimento de cada lineamento, somado e posteriormente dividido pela área do círculo que compreende o pixel do raster (OLIVERA et al., 2009). Os resultados do procedimento categorizaram a área da seguinte forma: muito baixa $(1,15)$, baixa $(1,65)$, intermediária $(2,16)$, alta $(2,67)$ e muito alta $(3,18)$. A classificação acima levou em conta a resposta da extração da densidade das feições. Isto permitiu identificar litologias mais fraturadas, pois estas sofreram maiores modificações ao decorrer da história geológica, expondo o regime dos principais eventos fissurais e acrecionais. 


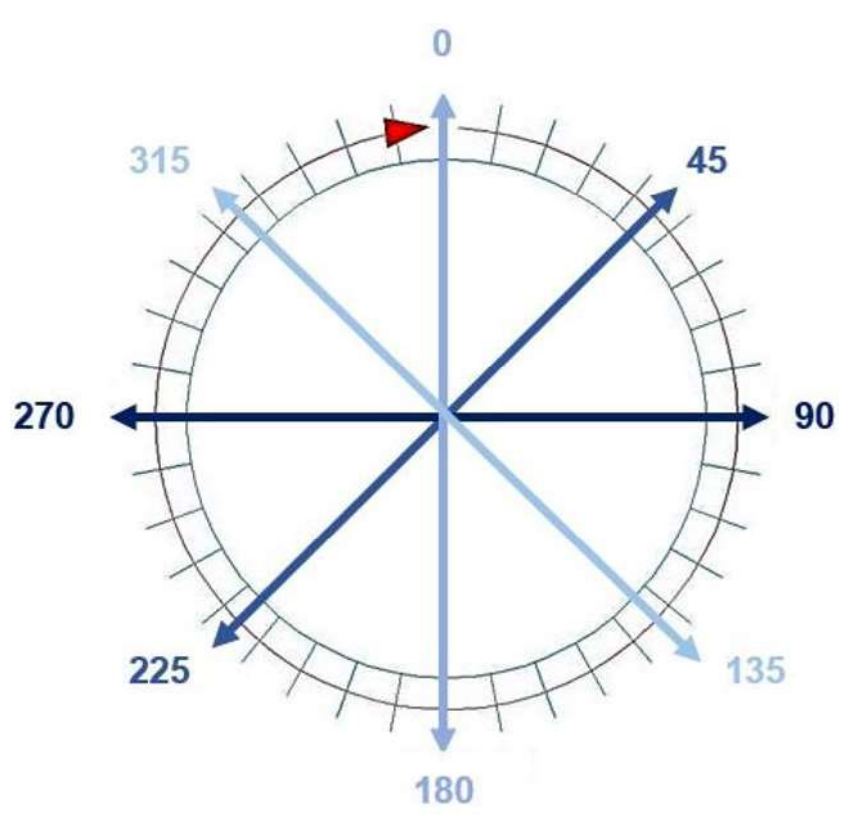

Figura 4 - Distribuição dos azimutes por quadrante. Em amarelo, estão destacados os 5 testes azimutais utilizados para o sombreamento das imagens SRTM.

\section{Resultados}

Os dados produzidos por este trabalho apontam para uma dissecação diferencial por controle estrutural dado a partir da densidade de fraturamento. $\mathrm{Na}$ área de estudo, as feições extraídas dos testes azimutais somaram um total de 15100 , em escala de vetorização 1:25.000. Os resultados obtidos através da extração de lineamentos estruturais mostraram três preferências principais (Figura 5), sendo destacadas as NE-SW (72.3\%), NW-SE (15,8\%) e, em menor expressividade, N-S $(5,0 \%)$.

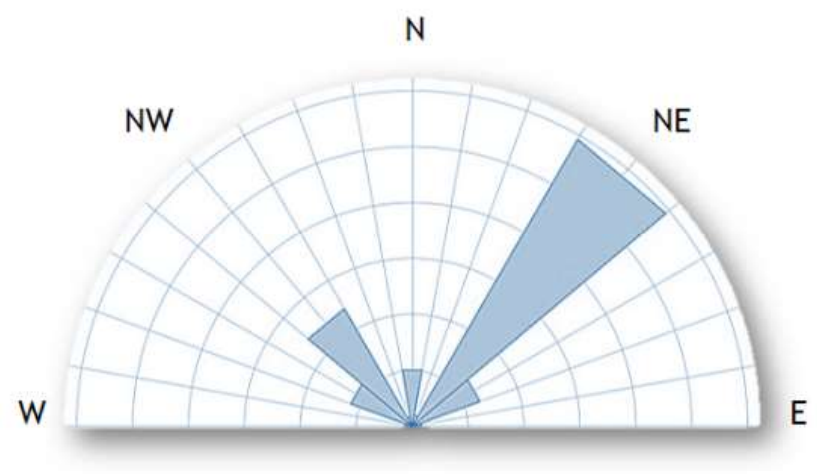

Figura 5-Roseta com a preferência dos lineamentos estruturais.

A distribuição NE-SW mostrada pela roseta apresenta o maior destaque, distribuída por todas as litologias e em toda a área de análise, com maior densidade no embasamento encaixante que desenha a superfície periférica aos maciços (Figura 6).

O padrão NW-SE apresenta expressiva quantidade de lineamentos, que estão presentes em todas as litologias, incluindo os granitoides brasilianos. Estes presenciam os setores mais fraturados, ao acompanharem porções com falhas ou fraturas. Deve-se salientar que, mesmo em menores proporções, esse direcionamento está mais presente nos setores com falhas NW-SE, com maior destaque no setor $\mathrm{C}$, onde os pontos de maior expressividade coincidem com a falha que atravessa tanto Maranguape quanto Aratanha.

A preferência N-S, embora em menor expressividade, está localizada nos setores relacionados com as falhas preexistentes, como é no caso da zona de cisalhamento N-S que segmenta os relevos de Juá e Conceição. Outra porção que pode ser destacada encontra-se a sul do relevo de Maranguape, no canto inferior esquerdo do setor $\mathrm{C}$, onde a alta densidade de lineamentos está vinculada a presença de duas falhas $\mathrm{N}-\mathrm{S}$. Esses lineamentos prosseguem no sentido N-S até encontrarem o setor $\mathrm{B}$, especialmente o paralelo ao relevo de Camará, que coincidentemente possui sua preferência nessa mesma direção. Este padrão também aparece no setor oeste do referido maciço, ao qual se vincula a presença de um setor falhado.

No tocante aos granitoides, estes possuem uma densidade de lineamentos (Figura 7) que pode ser diferenciada, sendo necessário atentar-se para a sua idade geológica. As rochas graníticas do Arco Magmático Santa Quitéria manifestam os estágios tectônicos brasilianos, repercutindo na disposição tanto do complexo quanto dos maciços, apresentando direção NE-SW. Já no caso dos Granitoides Diversos, os lineamentos apresentam a menor densidade de lineamentos, haja vista que a atividade plutônica deste setor se situou nos estágios finais das tensões crustais. Ambas as litologias apresentaram direções NE-SW, N-S e NW-SE.

Os lineamentos estruturais apresentam os relevos cristalinos como "sequelas" da dinâmica erosiva, posicionando-se enquanto altos topográficos em consequência de sua maior competência. Analisando as variáveis litologia, densidade de faturamento e altitude, é notável a forte correlação entre geologia e geomorfologia (Figura 8). 
Geomorfologia dos Maciços Costeiros da Região Metropolitana de Fortaleza, Ceará

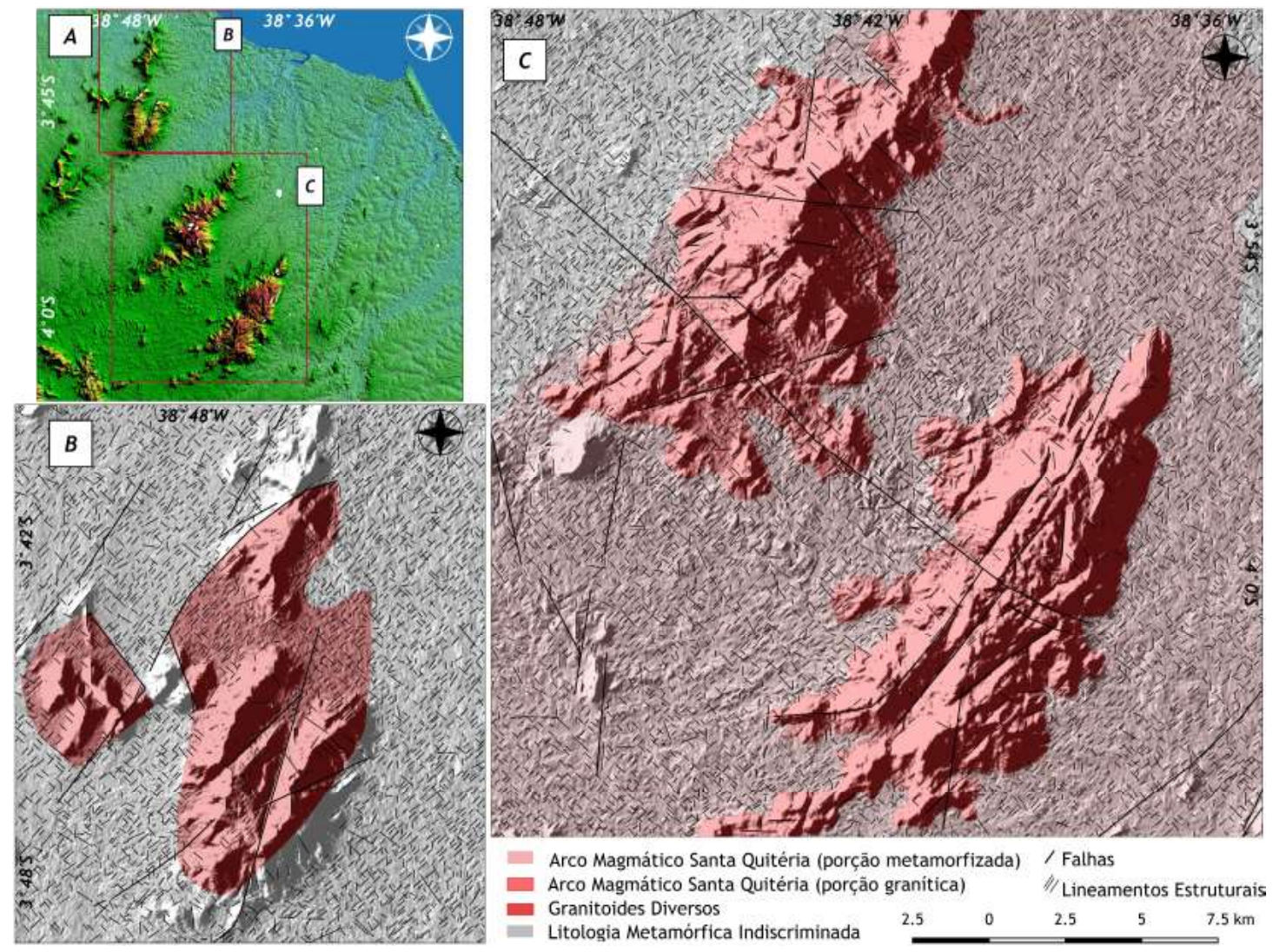

Figura 6 - Distribuição dos lineamentos estruturais. A - Área de estudos; B - Maciço de Juá/Conceição e Camará; C - Maciço de Maranguape e Aratanha.
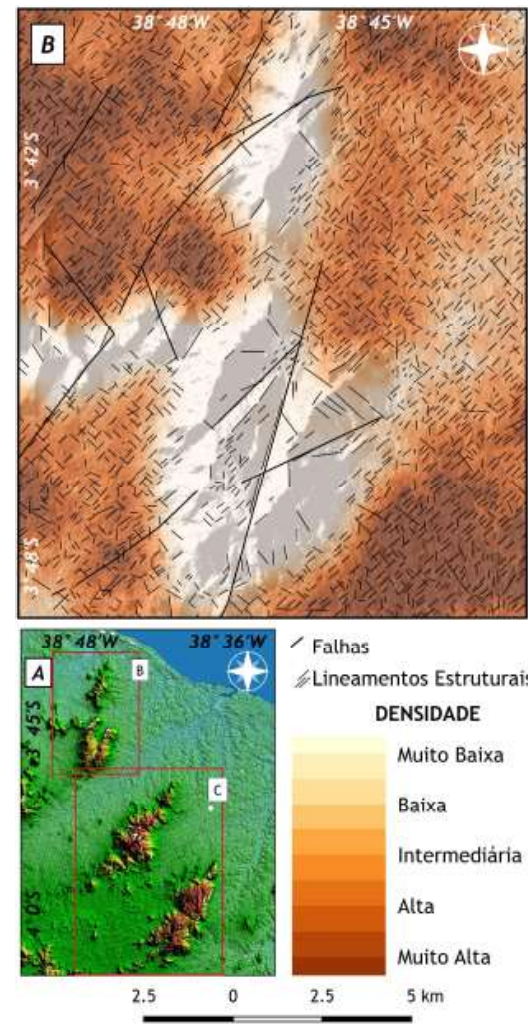

Figura 7 -Densidade dos lineamentos estruturais.

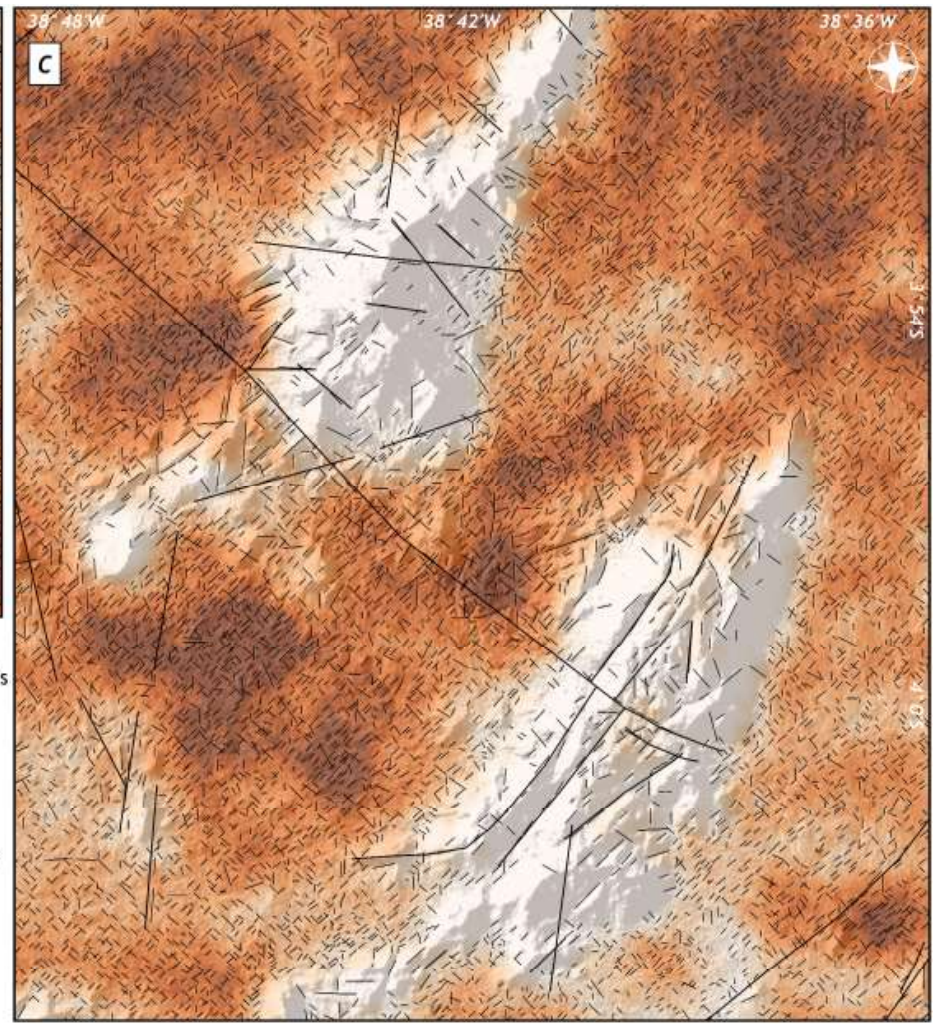

(2) 


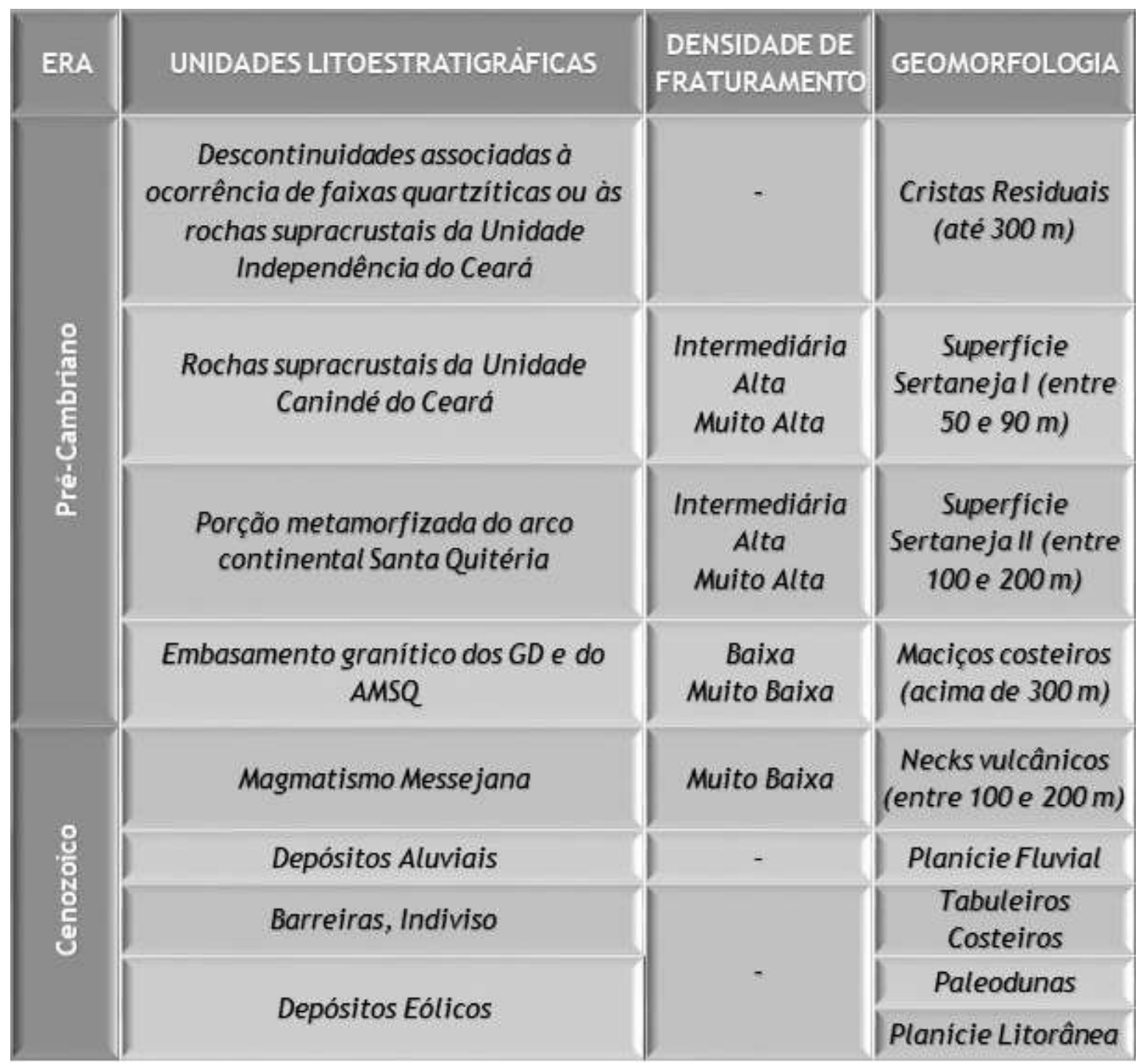

Figura 8 - Relação entre litologia, concentração de lineamentos e unidades de relevo.

A densidade de fraturamento é condicionante importante no padrão dissecativo da área, compartimentando as unidades morfoestruturais (Figura 9). Na área de estudo, os setores fortemente dissecados têm suas altimetrias mais baixas. $\mathrm{O}$ embasamento pode diferenciar as superfícies adjacentes aos maciços: o terreno correspondente ao $\mathrm{CC}$, por apresentar maior densidade de lineamentos, tem sua superfície alcançando altitudes médias de $60 \mathrm{~m}$. Na litologia de AMSQ, periférica aos relevos de Aratanha e Maranguape, a depressão alcança as maiores cotas, graças a sua maior resistência erosiva, alcançando as altimetrias máximas de $200 \mathrm{~m}$. Assim, as superfícies de erosão podem ser divididas em dois setores, a Superfície Sertaneja I, cujas cotas situam-se entre 50 e 90 m, e a Superfície Sertaneja II, entre 100 e $200 \mathrm{~m}$.
Os maciços costeiros, por apresentarem uma litologia granítica, tornaram-se menos susceptíveis à erosão, constituindo os setores menos fraturados. Levando ainda em consideração as fases de manifestação plutônica, há que se considerar a presença de feições rúpteis, como falhas e fraturas, responsáveis pelos setores pontuais de intermediária densidade, como no caso de Aratanha e, em especial, Maranguape. Sobre os maciços de Juá e Conceição, sua cristalização mais recente insere a zona de cisalhamento da área N-S como uma feição rúptil que assumiu o processo de exumação do corpo granítico.

No tocante ao embasamento encaixante, ele compreende a Superfície Sertaneja I, com taxas de fraturamento superior ao dos maciços. Este fato se deve 


\section{Geomorfologia dos Maciços Costeiros da Região Metropolitana de Fortaleza, Ceará}

ao metamorfismo regional decorrente da foliação NESW impressa na Unidade Canindé do Ceará, atrelada à presença mais consolidada de fraturas e zonas de cisalhamento. Os setores mais significantes coincidem com os pontos de falhas, com altimetrias mais baixas, em torno dos $60 \mathrm{~m}$. Já a porção correspondente ao AMSQ apresentou maior resistência, consolidando um caráter mais elevado à área. A partir da gradação do metamorfismo, as rochas expressam no relevo uma elevação altimétrica, até encontrar os relevos de Maranguape e Aratanha. As superfícies I e II apresentaram densidades intermediárias, altas e muito altas, com setores mais ou menos densos pela maior presença de falhas.

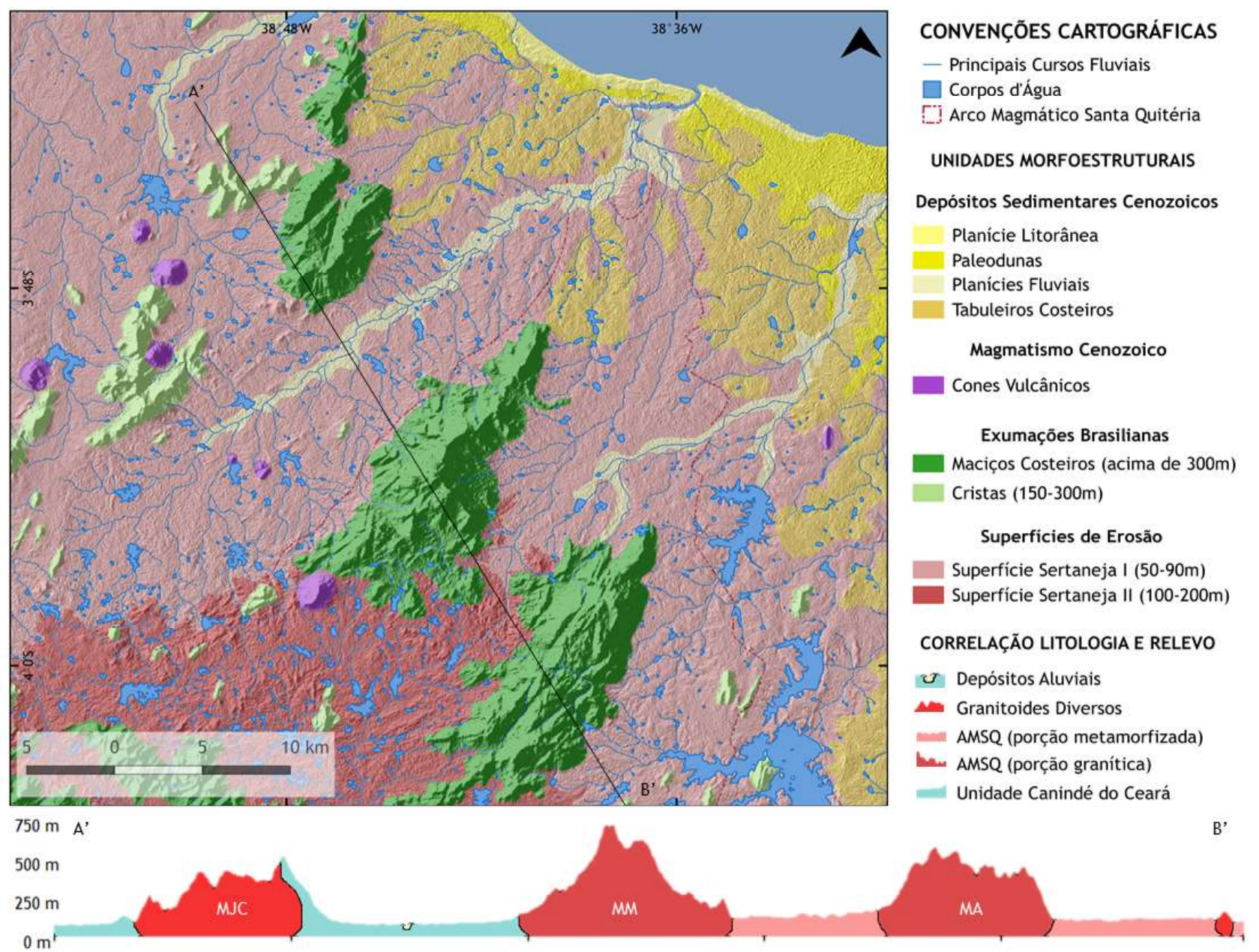

Figura 9 - Unidades geomorfológicas. MJC - Maciço de Juá/Conceição, MC - Maciço de Camará, MM - Maciço de Maranguape, MA - Maciço de Aratanha

As frações equivalentes às coberturas sedimentares cenozoicas, planícies aluviais e cristas residuais metamórficas não se encontram dentro dos setores $\mathrm{B}$ e C, não sendo, portanto, discutidas no presente trabalho. Seu afastamento dos recortes dos maciços justifica a sua ausência na interpretação de dados. Devemos destacar que a presença muito baixa nos setores próximos aos maciços está ligada à mancha urbana, que provocou rupturas nos dados de densidade. Já as porções mais dissecadas estão situadas no mesmo caso da Superfície Sertaneja, tendo o Rio Ceará como o trajeto mais fraturado, ao coincidir com falhas. Sua disposição NE-SW enfatiza esta assertiva.

Ao realizar a comparação entre morfologias e os padrões de fraturamento, fica evidente que os setores com maior concentração de lineamentos coincidem com a Superfície Sertaneja, representada pelo Complexo Ceará e por parte do AMSQ. Todavia, as porções com baixas distribuições de lineamentos constituem os lócus dos maciços costeiros, provenientes da exumação dos granitoides. 


\section{Discussão}

\subsection{Análise dos Lineamentos Estruturais}

As deformações provenientes dos esforços tectônicos produzem feições lineares ou levemente curvas que se transmite, no relevo, enquanto morfologias arrasadas ou destacadas (SABINS, 1996). Os lineamentos estruturais são definidos enquanto desenhos, destacados topograficamente, que esboçam os setores de fraqueza estrutural (JORDAN e SCHOTT, 2005), sejam eles rúpteis ou dúcteis. Quando dúcteis, eles representam a exumação de deformações nos setores mais profundos da crosta (MAIA e BEZERRA, 2014). Já as feições de caráter rúptil podem demonstrar o padrão de fraturamento por esforços superficiais tectônicos, bem como o alívio da pressão litostática, quando a rocha de subsuperfície chega à superfície.

As disposições NE-SW e N-S estão relacionadas aos esforços provenientes do amalgamento dos blocos continentais durante a colisão brasiliana que, na Província Borborema, repercutiu primeiramente no empilhamento das nappes, seguido da formação de diversas zonas de cisalhamento com as mesmas direções (NEVES et al., 1995). Já a distribuição N-S expressa a mudança no regime de deformação das rochas, outrora NE-SW e que graduou para N-S (VAUCHEZ et al., 1995). O terceiro padrão encontrado, NW-SE, está possivelmente relacionado aos campos de tensões pós-brasilianos, que poderiam ter afetado a área em análise a partir de fenômenos mais recentes (BEZERRA e VITA FINZI, 2000; FERREIRA et al., 1998; SAADI, 1993).

A direção NE-SW presente na rocha encaixante está vinculada à direção geral da gnaissificação no nordeste setentrional, onde o diaclasamento da rocha tende a ocorrer seguindo os planos de fraqueza existentes (LEINZ e AMARAL, 1987). O controle estrutural gera fraturas e foliações na rocha, padronizando os seus direcionamentos, induzindo à dissecação e composição dos vales fluviais, com maior potencial nos setores mais susceptíveis.

A ordenação das feições lineares na rocha encaixante possui uma variada quantidade de direções, sendo as principais delas NE-SW, N-S e NW-SE. Nesse contexto, as rochas pertencentes à Unidade Canindé do Ceará apresentam a mais densa distribuição de lineamentos nessa direção, haja vista que sua litologia se apresenta como sendo a mais antiga da área de análise.

O embasamento periférico aos relevos de Aratanha e Maranguape apresenta em sua constituição, rochas indicadoras de metamorfismos de alto a ultra-alto grau. Neste sentido, sua preferência mineralógica também acompanha a encaixante, NE-SW. As porções de densidades mais expressivas no AMSQ coincidem com os pontos de presença de fraturamentos nos sentidos NE-SW - orientação preferencial das rochas -, NW-SE e/ou N-S. Em outras palavras, a foliação apresentou-se como um importante fator de fraturamento, seguido dos esforços tectônicos subsequentes ao resfriamento da litologia, resultando numa maior dissecação da área.

No que corresponde aos setores menos arrasados pela ação erosiva, enfatizamos as intrusões brasilianas, posto sua maior resistência. Os granitoides que compõem os maciços costeiros ainda podem ser analisados de maneira separada, levando em conta a idade e o contexto no qual estão inseridos. Neste sentido, a litologia de AMSQ na área de estudo está representada por um granitoide sintectônico, sendo pertencente ao primeiro pulso de magmatismo (650-610 Ma). O fato de o AMSQ ser uma manifestação ocorrida no auge da orogenia indica que sua estruturação e orientação mineralógica estão ligadas aos campos de tensões vigentes, de trend NE-SW (COSTA et al., 2013; PITOMBEIRAe AMARAL, 2016).

As massas intrusivas sinorogênicas possuem uma estrutura fluidal paralela aos contatos da rocha circunjacente e uma coincidência geral com algumas das feições estruturais da encaixante (MIGON, 2006). Este processo decorre das influências endogenéticas e exogenéticas que submetem a intrusão granítica, até a sua consolidação final. (LEINZ e AMARAL, 1987). Tal fato é tão verídico que, se repararmos na disposição do arco magmático e dos relevos de Maranguape e Aratanha, este também está acompanhando o direcionamento estrutural do embasamento encaixante, NE-SW.

Os GD constituem os setores menos fraturados, o que resulta em sua maior resistência litológica. A associação com a sua geocronologia remete ao período intermediário ao segundo e terceiro pulsos de plutonismo (590 - $560 \mathrm{Ma} ; 540-520 \mathrm{Ma}$ ), onde os estágios finais da orogenia exerceram influência no alívio de pressão, favorecendo a intrusão de corpos graníticos. A estrutura fluidal, neste setor, encontra-se menos presente, mas ainda pode ser destacada, haja vista que as coletas petrográficas realizadas por Saraiva Junior (2009) detectaram a presença de monzogranito sintectônico. Os dados encontrados por este autor mostraram que o processo colisional, neste setor, não gerou bandas, entretanto os cristais possuem uma orientação seguindo o trend NE-SW. 


\section{Geomorfologia dos Maciços Costeiros da Região Metropolitana de Fortaleza, Ceará}

A presença de rochas metamórficas em setores mais elevados dos relevos de Juá/Conceição e Camará é expressa no relevo através dos lineamentos que estão ao redor do vale do Juá, cujo contexto assemelha-se à Unidade Canindé do Ceará. Tal afirmação é confirmada pelos trabalhos de campo do autor supracitado, ao atestar a existência do embasamento encaixante. Soma-se a isso, o relatório do mapeamento geológico coordenado por Brandão (1995), que afirmou a ocorrência de migmatitos nos dois relevos.

O cenário acima permite concluir que a exumação do granitoide foi possibilitada por meio de duas falhas presentes N-S e NE-SW, ligadas às tensões brasilianas e que as litologias metamorfizadas sustentam e "cobrem" parcela do corpo granítico, em virtude da ausência de fraturas e de sua resistência. Os padrões apresentados no setor B são também NW-SE, NE-SW e N-S, recebendo maior destaque os dois últimos, pois a presença de duas zonas de falha foi responsável pela separação dos relevos de Juá/Conceição e incisão do vale do riacho Juá. No setor adjacente aos maciços, o embasamento encaixante regional possui alta densidade de lineamentos estruturais, que estão relacionados a uma maior dissecação da área.

\subsection{Erosão Diferencial e Exumação dos Maciços Costeiros}

A organização do relevo da área de análise tem sua gênese por intermédio dos regimes compressivos e distensivos, sendo estes processos fundamentais à compreensão das morfologias, provenientes da estruturação geológica pretérita. No processo de evolução dos maciços costeiros, os agentes tectônicos foram importantes na estruturação de setores de falhas e fraturas, encontrando nos granitoides o ápice da atividade orogenética.

Os eventos decorrentes da Orogenia Brasiliana, do ponto de vista morfoestrutural, se configuraram como sendo os de maior importância para a litologia dos relevos cristalinos, pois sua estruturação é herdada dessa sequência de acontecimentos tectônicos (MAIA e BEZERRA, 2014). A colisão deu origem a uma cadeia de montanhas do tipo hymalaiana, que produziu um setor de elevado espessamento crustal de direção NE-SW (ARTHAUD, 2007), além das diversas zonas de cisalhamento, pelas quais estão relacionadas com a intrusão de diversos corpos granitoides (NEVES et al., 1995).

Após as fases finais, que se deram a partir dos esforços distensivos para a separação do Panotia, o cinturão orogenético passa por um colapso, sendo, em seguida, submetido aos primeiros processos de dissecação. Em virtude da maior calmaria tectônica entre o Brasiliano e o Cretáceo, os agentes externos passaram a dissecar a rocha, com maior preferência, nos setores mais propensos.

A calmaria tectônica perdurou durante a formação do megacontinente Pangea até o Cretáceo, quando aconteceu a fragmentação do Gondwana, num primeiro momento, em esforços extensivos NW-SE que culminaram na formação do rifte neocomiano Cariri/Potiguar (MATOS, 1992). Nesse momento, as zonas de cisalhamento brasilianas foram reativadas, e a erosão parece ter entrado em cena novamente de maneira mais intensa na porção correspondente aos maciços, pois estavam mais elevados, quando comparados com o setor submetido ao rifteamento.

Este rebaixamento do nível de base nos setores mais elevados teria possivelmente promovido uma indução da dissecação. Deve se destacar que os agentes externos passaram a atuar sobre o relevo a partir dos setores de maior fraqueza, levando em conta a litologia e os trends de lineamentos. Após o Barremiano começaram as ações tectônicas extensivas NW-SE e E-W, que formaram a margem continental no nordeste brasileiro (MAIA et al., 2010). Posteriormente, a ação erosiva exumou as suítes intrusivas.

O último episódio tectônico, mas de menor repercussão regional, foi o magmatismo que teve início no Paleógeno, com maior destaque durante o Oligoceno, resultando no denominado Magmatismo Messejana. $\mathrm{O}$ evento iniciou-se a partir do estabelecimento de um hotspot astenosférico, o que possibilitou uma atividade geotérmica considerável. As atividades cenozoicas foram influenciadas pela tectônica andina, bem como pela deposição sedimentar resultante da subsidência da placa oceânica. Como resultado, houve a reativação das falhas pré-cambrianas e de zonas de fratura oceânicas durante o Eoceno Médio, num regime compressivo NW-SE (CARNEIRO et al., 1989). Essa atividade foi facilitada pelo fato de que a área de estudo é um prolongamento da zona transformante de Fernando de Noronha (ALMEIDA, 2006). Este fato ainda repercutiu geomorfologicamente numa sequência de necks posicionados em forma de arco, possivelmente graças à menor densidade de falhas que $\mathrm{o}$ AMSQ apresentou (COSTA, 2008).

O desgaste da área passa a ter maior ênfase a partir do Neógeno, quando a geomorfologia da área vivenciou as variações eustáticas e climáticas, refletidas na posterior deposição de sedimentos que foram transportados dos maciços costeiros em direção ao litoral. Nesse momento, a ação da flexura marginal pareceu destacar-se de forma 
diferente nesse setor, onde a forte espessura crustal e a ausência de zonas de cisalhamento regionais justificariam a maior resistência ao processo de subsidência da margem continental (CLAUDINO-SALES, 2016). Alguns estudos elaboraram estimativas, no qual apontaram uma taxa de aproximadamente $300 \mathrm{~m}$ de erosão a partir do vulcanismo (PEULVAST et al., 2008).

Durante o Cenozoico, as alternâncias climáticas foram de grande papel (CLAUDINO-SALES e PEULVAST, 2007) à modelagem dos maciços, especialmente através das transições de períodos úmidos e secos, influenciando na erosão, transporte e deposição. Sobre este aspecto, o modelo teórico da etchplanação explana que a formação do relevo acontece em razão da inconstante associação estabelecida entre a superfície e o seu front de alteração, de acordo com as condições climáticas (VITTE, 2005). Destarte, as oscilações climáticas intensificam os processos morfogenéticos, sobretudo de um clima úmido para um clima seco, haja vista que tal processo promoveu uma remoção do manto de alteração que fora formado na fase anterior. Os agentes fluviais constituíram-se como interface dos fatores tectônicos e climáticos, pois sua atividade reflete nos processos de erosão, transporte e deposição, exumando as rochas de subsuperfície.

As descontinuidades das rochas são controles-chave dos processos geomórficos que operam nas paisagens graníticas (MIGON, 2006). Na morfogênese, falhas, fraturas e a alteribilidade das rochas são componentes que condicionam a velocidade da alteração, através dos processos fluviais e dos movimentos de massa (VITTE, 2005).

Sendo assim, no setor correspondente aos granitoides, as fraturas existentes (Figura 10, Bloco 1) induziram o processo erosivo a desgastar a rocha, onde foi produzido um front de alteração, num ambiente mais úmido (Figura 10, Bloco 2). As reativações tectônicas cenozoicas trouxeram à área a acentuação da dissecação. Com as alternâncias climáticas, especialmente na transição de clima úmido para seco, aconteceu a remoção da superfície pedogenética, individualizando ainda mais os maciços costeiros (Figura 10, Bloco 3).

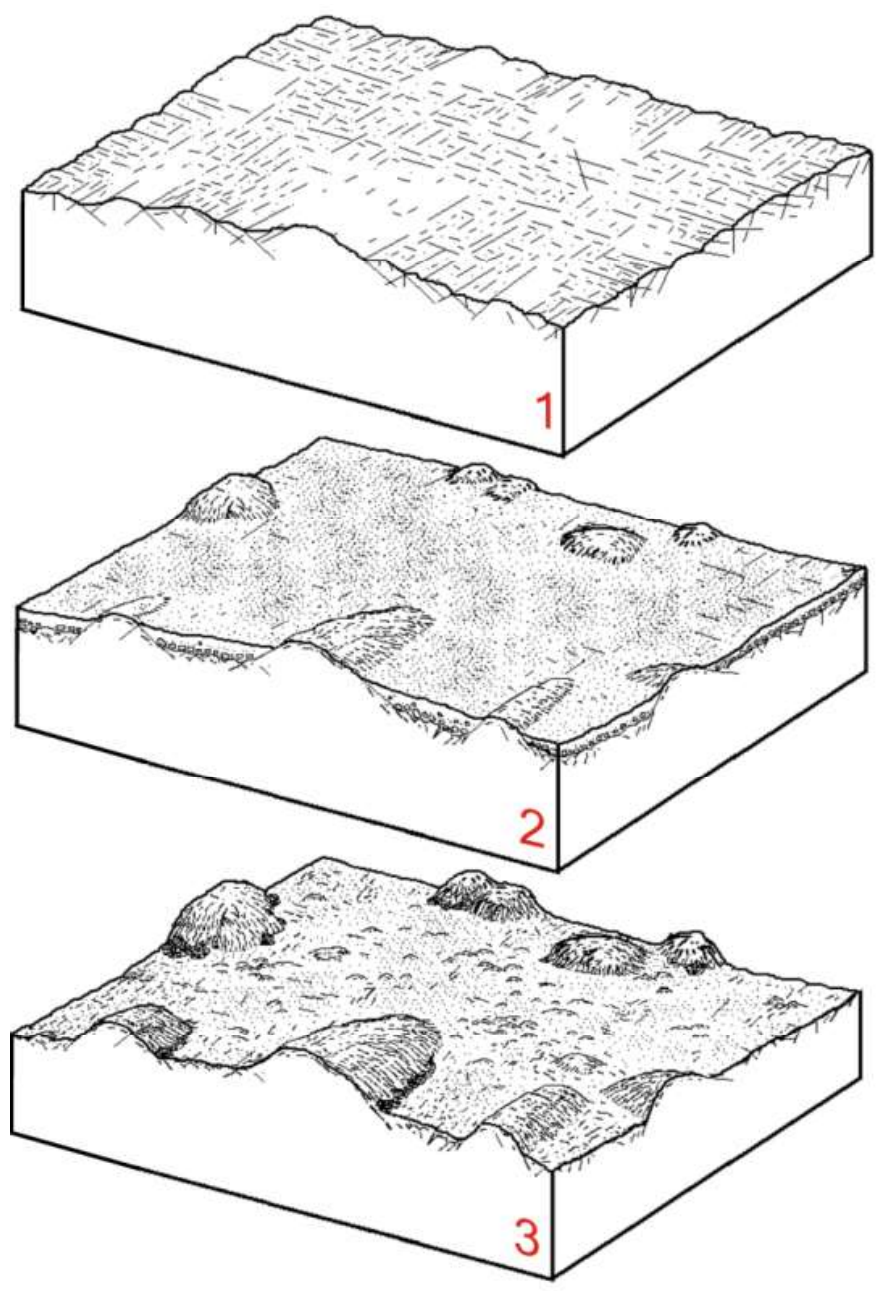

Figura 10 - Erosão diferencial e exumação dos maciços costeiros. 
O embasamento é exumado à superfície a partir das remoções dos setores intemperizados, expostos de acordo com os trends estruturais. A erosão expõe enquanto sobressaltos topográficos os setores da superfície basal de intemperismo que não sofreram alteração (VITTE, 2005), por meio da ausência de fraturas. Assim, os maciços costeiros são resultantes da remoção dos detritos friáveis oriundos da instabilidade climática, por meio da erosão diferencial, aliados às influências estruturais e tectônicas.

\section{Considerações Finais}

O Ceará possui uma diversidade geomorfológica resultante da erosão diferencial, em associação aos variados tipos de embasamento, bem como às condições e variações climáticas. Desta forma, os maciços costeiros são expressões em superfície dos eventos de subsuperfície, exumados pelos processos denudacionais, cuja ação é seletiva.

Através do processamento digital de imagens, e em combinação com o conhecimento prévio da área, detectou-se que as preferências dos principais lineamentos estruturais estavam relacionadas à colisão neoproterozoica (NE-SW e N-S) e à formação da margem continental no Cretáceo, bem como aos campos de stress mais recentes (NW-SE). A densidade de feições lineares apresentou-se em maior expressividade nos setores encaixantes aos granitoides, bem como às porções com maior concentração de falhas e/ou fraturas.

Os regimes tectônicos, em associação com os elementos litológicos e estruturais permitiram concluir que a densidade de faturamento, na área de análise, foi importante condicionante para a evolução das formas de relevo, com destaque para a Superfície Sertaneja I, embasada pelo CC, a Superfície Sertaneja II, representada pelo setor metamorfizado do Arco Magmático de Santa Quitéria e os Maciços Costeiros, constituídos pela litologia granítica dos Granitoides Diversos (Maciço de Juá/Conceição e Camará) e do AMSQ (Maciços de Maranguape e Aratanha).

O papel da erosão diferencial na área em análise se deu mediante o intemperismo divergente, consoante com as estruturas preexistentes. As zonas de falhas, estruturadas no Brasiliano, foram reativadas durante a divisão do Gondwana e o Paleógeno. Os agentes externos trabalharam mais expressivamente sobre as litologias mais fraturadas e, portanto, mais fragilizadas, no embasamento composto pelas rochas metamórficas do Grupo Ceará e do AMSQ, de relevo mais aplainado. A maior resistência litológica preservou os setores de granitoides, individualizando os maciços costeiros.

\section{Referências Bibliográficas}

ANCELMI, M. F., DOS SANTOS, T. J. S., REGINATO, R. A., AMARAL, W. S., MONTEIRO, L. V. S., Geologia da faixa Eclogítica de Forquilha, Domínio Ceará Central, noroeste da Província Borborema., Brazilian Jounal of Geology, p. 235252, 3013.

ARAÚJO C.E.G.; CORDANI U.G.; BASEI, M.A.S.; CASTRO, N.A.; SATO, K.; SPROESSER, W.M. U-Pb detrital zircon provenance of metasedimentary rocks from the Ceará Central and Médio Coreaú Domains, Borborema Province, NE-Brazil: Tectonic implications for a long-lived Neoproterozoic active continental margin. Precambrian Research, 206-207:36-51, 2012.

ARTHAUD, M. H., FUCK, R. A., DANTAS, E. L., SANTOS, T. J. S., CABY, R., ARMSTRONG, R., 2015. The Neoproterozoic Ceará Group, Ceará Central domain, NE Brazil: Depositional age and provenance of detrital material. New insights from $\mathrm{U}-\mathrm{Pb}$ and Sm-Nd geochronology. Journal of South American Earth Sciences, 58, 223-237.

ARTHAUD, M.H. Evolução Neoproterozoica do Grupo Ceará (Domínio Ceará Central, NE Brasil): da sedimentação à colisão continental brasiliana. Tese (Doutorado em Geociências) - Instituto de Geociências da Universidade de Brasília. Brasília, 2007.

ARTHAUD, M.H.; CABY, R.; FUCK, R.A.; DANTAS, E.L.; PARENTE, C.V. Geology of the northern Borborema Province, NE Brazil and its correlation with Nigeria, NW Africa. In: Pankhurst R.J., Trouw R.A.J., Brito Neves B.B., de Wit M.J. (eds.). West Gondwana: PreCenozoic Correlation Across the South Atlantic Region. Geological Society, London, Special Publications, 294:49-67, 2008.

BRANDÃO, R.L. Sistema de informações para gestão e administração territorial da Região Metropolitana de Fortaleza Projeto SINFOR: Mapa geológico da Região Metropolitana de Fortaleza. Texto explicativo. Fortaleza: CPRM, 1995.

BRASIL. Ministério das Minas e Energia. Secretaria Geral. Projeto RADAMBRASIL. Folha SA. 24 Fortaleza; geologia, geomorfologia, pedologia, vegetação e uso potencial da terra. Rio de Janeiro, 1981. 
BIGARELLA, J.J.; BECKER, R.D.; SANTOS, G.F. dos. Estrutura e origem das paisagens tropicais e subtropicais. 2 ed. Vol. 3. Florianópolis: UFSC, 2007.

CABY, R.; ARTHAUD, M. Major Precambrian nappes of the Brazilian belt, Ceará, northeast Brazil. Geology, 14: 871-874, 1986.

CARNEIRO, C. D. R.; HAMZA, V. M.; ALMEIDA, F.F. M. Ativação tectônica, fluxo geotérmico e sismicidade no Nordeste Oriental brasileiro. Revista Brasileira Geociências, 19 (3), p.310-322, 1989.

CAVALCANTE, A. Jardins suspensos no sertão. Revista Scientific American Brasil. Disponível em: $<$ http://www.insa. gov.br/wp-content/uploads/2013/05/Jardins-Suspensos.pdf $>$. Acesso em 13 de set. 2016.

CAVAlCANTE, J. C. et al. Mapa geológico do Estado do Ceará - Escala 1:500.000. MME/CPRM. 2003.

CLAUDINO-SALES, V. Megageomorfologia do Estado do Ceará. Novas Edições Acadêmicas, 2016.

CLAUDinO SALES, V.C.; PEULVAST, J.P. Evolução morfoestrutural do relevo da margem continental da do Estado do Ceará, nordeste do Brasil. Revista Caminhos da Geografia, Uberlândia, v.7, n. 20, 2007.

CLAUDINO-SALES, V.C. Les littoraux du Ceará - Evolution géomorphologique de la zona côtiere de l'Etat du Ceará, Nod-est du Brasil. These (Doctorat) - Université ParisSorbonne IV, 2002.

CORDEIRO, A. M. N. Análise socioambiental da sub-bacia hidrográfica do Rio Pirapora - Maranguape/Ceará, como subsídio ao planejamento territorial e à gestão ambiental. 2008, 166f. Dissertação (Mestrado) Curso de Pós Graduação em Geografia, Universidade Estadual do Ceará, Fortaleza, 2013.

COSTA, F.G. da.; ARAÚJO, C.E.G. de.; AMARAL, W. da S.; VASCONCELOS, A.M.; RODRIGUES, J.B. U-Pb (LAICPMS) zircon ages and Nd isotopes for granitoids the TamborilSanta Quitéria Complex, Ceará Central Domain: implication for neoproterozoic syncollisional magmatism in north Borborema Province. Geologia USP, São Paulo, v.13, n.2, p. 159-174, 2013.

COSTA, F.G., de ARAÚJO, C.E.G, VASCONCELOS, A.M., PALHETA, E.S.M, JUSTO, A.P. 2010. O Complexo TamborilSanta Quitéria: evidências de slab breakoff durante colisão continental neoproterozoica, norte da Província Borborema. 45 $^{\circ}$ Congresso Brasileiro de Geologia, Belém, PA.

COSTA, A.T. da. Evolução Morfoambiental dos Relevos
Vulcânicos da Região Metropolitana de Fortaleza. 2008, $135 f$. Dissertação (Mestrado) Curso de Pós Graduação em Geografia, Universidade Federal do Ceará, Fortaleza, 2008.

FETTER A.H.; SANTOS T.J.S.; VAN SCHMUS W.R.; HACKSPACHER P.C.; BRITO NEVES B.B.; ARTHAUD M.H.; NOGUEIRA NETO J.A.; WERNICK E.. Evidence for Neoproterozoic Continental Arc Magmatism in the Santa Quiteria Batholith of Ceará State, NW Borborema Province, NE Brazil: Implications for the Assembly of West Gondwana. Gondwana Research, v. 6, n. 2, p. 265-273, 2003.

GURGEL, S. P. de P. Evolução Morfotectônica no Maciço Estrutural Pereiro, Província Borborema. 2012, 204f. Tese (Doutorado) Curso de Doutorado em Geodinâmica e Geofísica, Universidade Federal do Rio Grande do Norte, Natal, 2012.

JORDAN, G.; SCHOTT, B. Application of wavelet analysis to the study of spatial pattern of morphotectonic lineaments in digital terrain models. A case of study. Remote Sensing of Environment, 94, p. 31-38. 2005

LEINZ, V; AMARAL, S.E. Geologia Geral. 10a ed. São Paulo: Companhia Editora Nacional, 1987, 399 p.

LIMA, E. C. A Importância das Serras Cristalinas no Semiárido do Nordeste, Especialmente no Ceará-Brasil. Revista da Casa Geografia de Sobral, Sobral, v. 16, n. 1, p. 89 - 100, 2014.

MAIA, R. P.; BÉTARD, F.; BEZERRA, F. H. R..Geomorfologia dos maciços de Portalegre e Martins - NE do Brasil: Inversão do relevo em análise. Revista Brasileira de Geomorfologia, Brasil, v. 17, n. 2, p.274-285, 2016.

MAIA, R. P.; NASCIMENTO, M.A.L. do; BEZERRA, F. H. R.; CASTRO, H.S de; MEIRELES, A.J. de A. Geomorfologia do Campo de Inselbergues de Quixadá, Nordeste do Brasil. Revista Brasileira de Geomorfologia, Brasil, v. 16, n. 2, p.239-253, 2015.

MAIA, R. P.; BEZERRA, F. H.R. Tópicos de Geomorfologia Estrutural: Nordeste Brasileiro. Fortaleza: Edições UFC, 2014.

MAIA, R. P.; CLAUDINO-SALES, V. C.; BEZERRA, F. H.R. Geomorfologia do Nordeste: concepções clássicas e atuais acerca das superfícies de aplainamento nordestinas. Revista de Geografia. Recife: UFPE - DCG/NAPA, v. especial VIII SINAGEO, n. 1, Set. 2010

MATOS, R. M. D. The Northeast Brazilian Rift System. Tectonics. 11 (4): 766-791, 1992.

MIGON, P. Granite Landscapes of the World. New York: 


\section{Geomorfologia dos Maciços Costeiros da Região Metropolitana de Fortaleza, Ceará}

Oxford, 2006.

NASCIMENTO, D.A. do; GAVA, A; PIRES, J. de L.; TEIXEIRA, W. Geologia. Mapeamento Regional.In: Projeto RADAMBRASIL. Folha SA.24- Fortaleza. Rio de Janeiro: 1981, v. 21, p.23-133.

NEVES, S. P.; VAUCHEZ, A.; ARCHANJO, C. J. Shear zonecontrolled magma emplacement or magma assisted nucleation of shear zones? Insights from northeastern Brasil. Tectonophysics, v. 262 , p. $349-364,1995$.

OLIVERA, D. B. de; MORENO, R. da S.; MIRANDA, D. J. de; RIBEIRO, C. da S.; SEOANE, J. C. S.; MELO, C. L. Elaboração de um mapa de lineamento estrutural e densidade de lineamento através de imagem SRTM, em uma área ao norte do rio Doce, ES. XIV Simpósio Brasileiro de Sensoriamento Remoto. Natal, RN.

PEULVAST, J.P.; CLAUDINO, S. V; BÉTARD, F.; GUNNELL, Y. Low post Cenomanian denudationdepths across the Brazilian Northeast:Implications for long-term landscape evolution at a transforCamaráontinental margin. Global and Planetary Change. N. 62, p. 39-60.2008.

PITOMBEIRA, J.P.A.; AMARAL, W. S. Petrografia e Geoquímica do Complexo Granito-Migmatítico de PalmáciaPacatuba-Maranguape, Domínio Ceará Central, província Borborema: Evidências de um arco magmático Neoproterozoico. $\mathbf{4 8}^{\circ}$ Congresso de Geologia, Porto Alegre, RS.

PINÉO, T.R.G.; ZWIRTES, S. 2013. Programa Geologia do Brasil-PGB. Baturité. Folha SB.24-X-A-I. Estado do Ceará. Carta Geológica. Fortaleza: CPRM, 2013, 1 mapa colorido, 96 x 67,5 cm. Escala 1:100.000.

SAADI, A. Neotectônica da Plataforma Brasileira: esboço e interpretação preliminares. Gnomos Revista de Geociências (1), p. 1-15, 1993.

SABINS, Jr., F.F. Remote sensing: principles and interpretations. Freeman and Company, 494p. 1996.

SANTOS, E. J.; BRITO NEVES, B.B. Província Borborema. In: ALMEIDA, F. F. M.; HASUI, Y. (Coord.). O Pré-Cambriano do Brasil. Edgard Blücher Ltda, p. 123-160.

SARAIVA JUNIOR, J. C. Geomorfologia dos Maciços Costeiros de Caucaia, Ceará. 2009, 151f. Dissertação (Mestrado) Curso de Pós Graduação em Geografia, Universidade Federal do Ceará, Fortaleza, 2009.

SOUZA, G.M. Modelagem Ambiental para a Delimitação de Brejos de Altitude com Estudo de Casos para os Maciços da Aratanha, Maranguape, Juá e Conceição - Estado do Ceará. 2014, 139f. Dissertação (Mestrado) Mestrado Acadêmico em Geografia, Universidade Estadual do Ceará, Fortaleza, 2014.

SOUZA, M.J.N. Contribuição ao estudo das unidades morfoestruturais do Ceará. Revista de Geologia, Fortaleza, 1988.

VASCONCELOS, A. M.; TORRES, P. F. M.; FORGIARINI, L.L.; MEDERISO, M. de F.Folha SA.24-Fortaleza. In: SCHOBBENHAUS, C.; GONÇALVES, J. H.; SANTOS, J. O. S.; ABRAM, M. B.; LEÃO NETO, R. MATOS, G. M. M.; VIDOTTI, R. M.; RAMOS, M. A. B.; JESUS, J. D. A. de. (eds.) Carta Geológica do Brasil ao Milionésimo, Sistema de Informações Geográficas. Programa Geologia do Brasil. CPRM, Brasília. CD-ROM.

VITTE, A.C. Etchplanação dinâmica e episódica nos trópicos quentes e úmidos. Revista do Departamento de Geografia da USP, São Paulo, n. 16, p. 105-118, 2005. 